\title{
DE TORENS VAN OUDE TEMPELS IN INDIA
}

Oude tempels in India hebben dikwijls hun torens verloren. Omdat er verschillende bouwstijlen zijn (Nagara, Dravida, Vesara) die zich juist door hun verschillende soorten torens onderscheiden, geeft dit problemen bij classificatie en reconstructie van de tempels. Oude hindoe-teksten over architectuur (silpasastras) geven geen oplossing voor dit morfologische probleem. ${ }^{1}$ Maar in de onderbouw van de tempels zijn verschillende stijlen te onderscheiden, en bijna altijd geeft die onderbouw aan hoe een verloren bovenbouw er uit zag. Met name enkele beroemde Hoysala tempels hebben hun bovenbouw verloren, maar er kan weinig twijfel bestaan over hun karakter.

\section{Hindoe-torens}

Torens zoals christelijke kerken die hebben, in de vorm van een meestal vierkante cilinder, komen in hindoe-architectuur niet voor. Er is één uitzondering: in het fort van Chittaurgarh in de deelstaat Rajasthan staan twee zulke torens, beide met een uitgesproken hindoe karakter (afb. 1). Ze zijn vierkant en hebben gevels met verdiepingen die door typische hindoebouwelementen worden gevormd, en die versierd zijn zoals middeleeuwse hindoe-tempels. Deze twee torens zijn uniek. Gewone hindoe-torens zijn een soort piramides die rusten op een kubusvormige onderbouw.

\section{Hindoe-tempels}

Kerken en moskeeën zijn bedoeld om grote aantallen gelovigen onderdak te bieden tijdens godsdienstoefeningen. Aan een grote binnenruimte zijn vaak een of meer torens toegevoegd. Die torens hebben een praktische functie, voor klokken of voor de oproep tot gebed, en natuurlijk ook een belangrijke psychologische functie: het benadrukken van de belangrijkheid van het gebouw. Hindoe-tempels zijn anders van opzet. Ze zijn de behuizing van een god, en bestaan in principe alleen maar uit een kleine kamer waarin een cultusbeeld staat. Vaak is aan deze cella een hal toegevoegd, maar die is niet groot en alleen bedoeld voor een kleine groep mensen die daar toezien hoe de priester in hun naam cultushandelingen verricht. De cella is het enige belangrijke, en die is daarom uitgerust met een toren. Die toren is een bekroning die een geheel vormt met de onderbouw, van een aparte toren is geen sprake. De toren geeft de plaats aan waar de god resideert. Een uitzondering vormen sommige grote tempels in Tamil Nadu in het uiterste zuiden van India, daar zijn het de toegangspoorten tot het tempelgebied die van piramideachtige torens (gopuras) zijn voorzien, terwijl de cella soms 

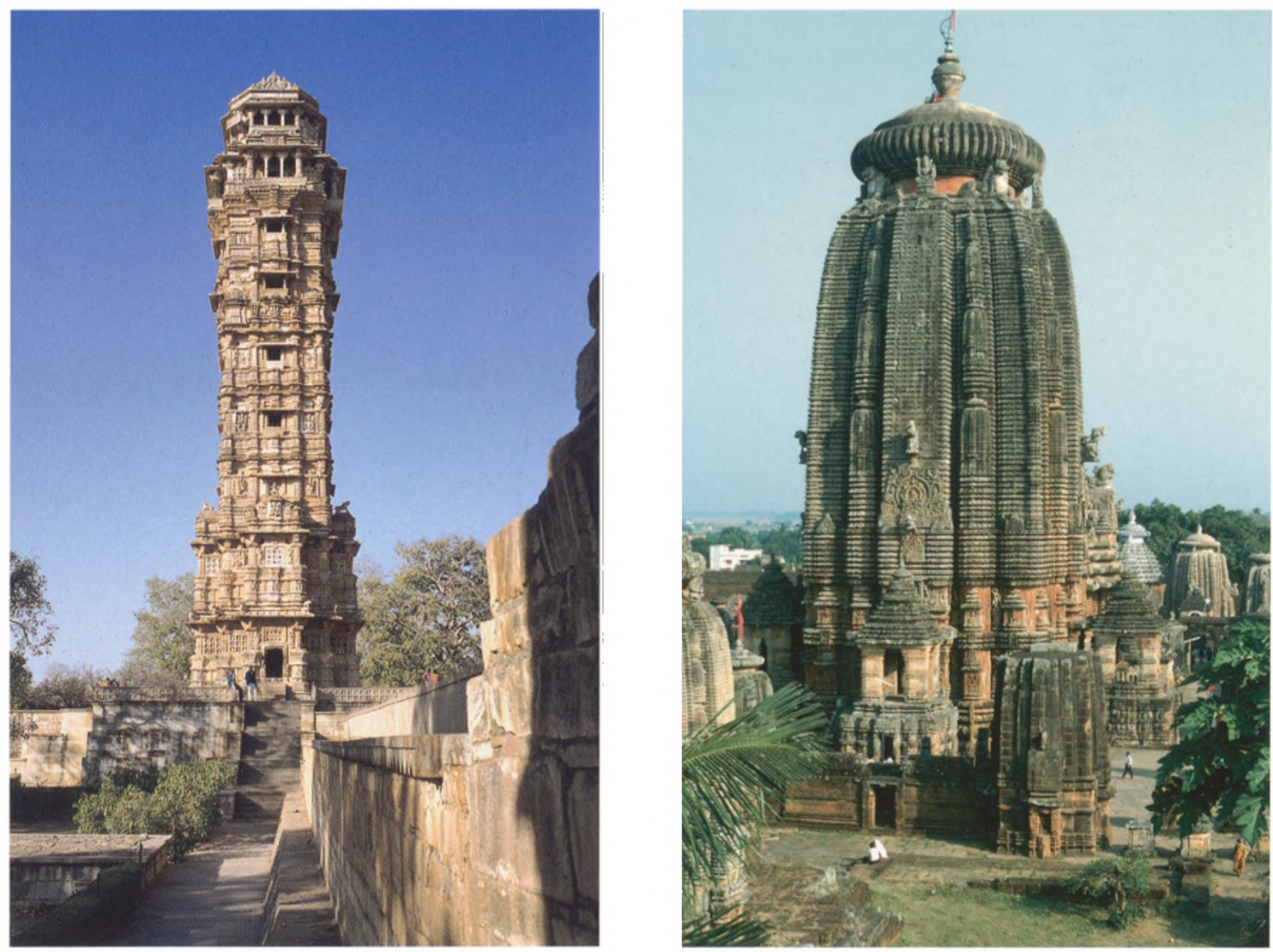

Afbeelding 1 (links)

Kirti-stambha,

Chittaurgarh, Rajasthan, $15^{\mathrm{e}}$ eeuw.

\section{Afbeelding 2}

Lingaraja-tempel, Bhubaneswar, Orissa, $11^{e}$ eeuw. wordt bijzonder effectief voorkomen door de bouwmassa een lichte concave buiging te geven. In het noorden van India wordt de stijfheid van piramideachtige torens juist voorkomen door een lichte convexe buiging.

\section{De muren van de tempel}

De tempel bestaat uit een cella voor een cultusbeeld. Het latijnse woord 'cella' roept een juiste associatie op, het is een kleine vierkante ruimte die als regel kaal is, zonder enige versiering, en die alleen maar een deuropening heeft, geen vensters. De muren zijn dik en daardoor is de buitenkant aanmerkelijk groter. Die buitenkant is wél versierd, vaak met beeldhouwwerk en altijd met architectuurelementen. De blinde muren worden verlevendigd door het midden en de hoeken te laten uitspringen. Het aantal uitsprongen kan groter zijn dan drie per kant, en zij kunnen een speciaal patroon vormen, een ruit of een ster. Elke uitsprong heeft een eigen bekroning. In het zuiden van India is dit een kapvormig dakje. In het noorden van India is dit meestal een daktorentje, een kleine piramide met zwak gebogen ribben. De kapvormige daken kunnen verschillende vormen hebben, maar ze zijn allemaal afgeleid van rieten daken, en het zijn typische architectuurelementen van de bouwstijl die Dravida wordt genoemd. De daktorens met gebogen convexe ribben worden vaak sikhara gemoemd, en zijn het architectuurelement bij uitstek van de bouwstijl die Nagara wordt genoemd. De uitsprongen van de buitenmuren van de cella verschillen nietalleet in hur bekroning. $6 / 2023$ 10:14:14AM Uitsprongen met Dravida daken zijn op hun hoeken altijd voorzien via frange 
dunne pilasters en suggereren daardoor elk een langgerekt houten gebouwtje. Uitsprongen bekroond met kleine Nagara sikharas hebben de vorm en de versieringen van hindoe-pilaren, en zijn niets anders dan een pilaar met een bekroning. Ook in dit geval suggereert elke uitsprong een langgerekt afzonderlijk gebouw.

\section{De toren van de tempel}

De cella met zijn dikke muren wordt bekroond door een toren die eigenlijk beter een piramide genoemd kan worden. Maar het stijve karakter van een piramide ontbreekt, en ook een puntige top ontbreekt. Het is gebruikelijk te spreken van bovenbouw (superstructure). In het geval van Dravida tempels bestaat de bovenbouw uit verkleinde herhalingen van het bovenste stuk van de muren en tenslotte een groter kapvormig dak. Bij twee of meer herhalingen resulteert dit in een getrapte piramide (afb. 2). In het geval van Nagara tempels zijn er meerdere mogelijkheden: een grote sikhara in het centrum omgeven door de kleintjes die de uitsprongen van de muren bekronen (sekhari-stijl) of een veelvuldige herhaling van de kleintjes binnen de vorm van één grote (bhumija-stijl) (afb. 3). Ook kunnen de kleine sikharas ontbreken, elke uitsprong van de muren heeft dan een uitsprong van de grote sikhara als bekroning (latina-stijl).

Resultaat: Dravida tempels worden bekroond met een trappiramide en Nagara tempels met een piramide die een elegant gebogen silhouet heeft. Dit verschil is het duidelijkste onderscheid tussen de twee genoemde hindoebouwstijlen.

\section{De verschillende tempelstijlen}

Als het silhouet van de bovenbouw als criterium wordt genomen voor de bouwstijl van een tempel dan is er een derde stijl te onderscheiden (Vesara), want in Karnataka, de zuid-westelijke deelstaat grenzend aan het alom bekende Goa, komen tempels voor met een silhouet dat het midden houdt tussen een rechte getrapte en een gebogen vloeiende lijn. Karnataka is ook het enige gebied in India waar de Dravida en Nagara bouwstijlen naast elkaar voorkomen, soms zij aan zij. Voor onderzoekers van tempelarchitectuur is het daarom het interessantste gebied in India, de afgelopen jaren zijn er maar liefst drie onderzoekers op gepromoveerd. ${ }^{2}$ Op de muren van Karnataka tempels worden dikwijls als decoratie Dravida en Nagara torens naast elkaar afgebeeld tezamen met vele fantasievolle tussenvormen die in werkelijkheid niet bestaan, maar wel duidelijk het idioom van de tempelbouwers demonstreren. De gebouwde tempels zijn echter altijd óf Dravida of Nagara. Door de vermenigvuldiging en miniaturisering van bouwelementen in latere Dravida tempels in Karnataka krijgt het silhouet van hun bovenbouw een vloeiende lijn.

\section{Ontbrekende torens}

Veel oude Indiase tempels zijn in de loop der tijd ruïnes geworden, en met name hun bovenbouw is vaak verloren gegaan. De onderbouw is bijzonder goed bestand tegen verwaarlozing, maar de bovenbouw veel minder. De onderbouw is altijd van natuursteen gemaakta de bovenbouw kanrook 2 van : 14:14AM baksteen zijn. In de ruïnestad Vijayanagara (Karnataka, $16^{\mathrm{e}}$ eeuw) vâllen de de ${ }^{\text {access }}$ 


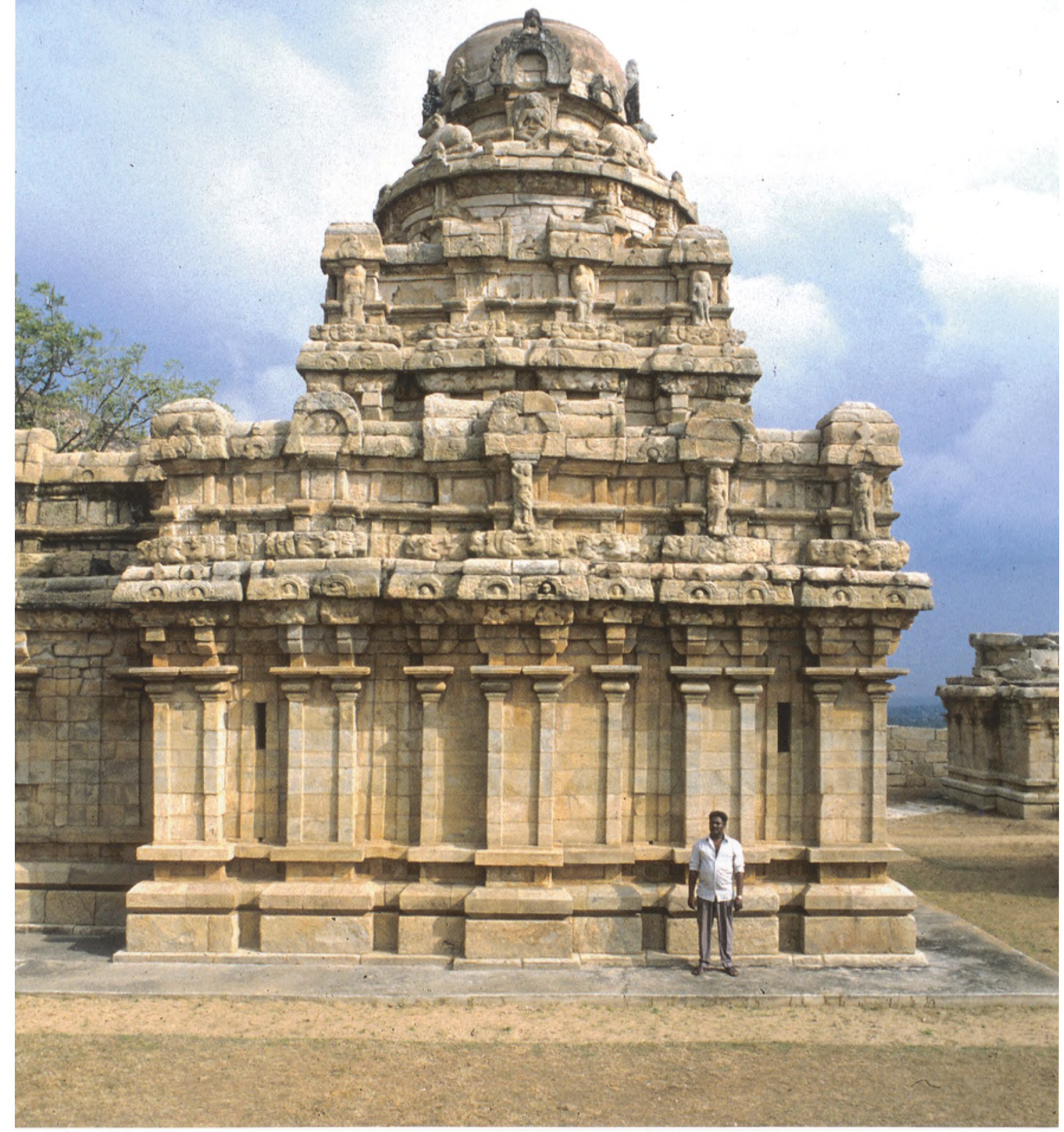

Afbeelding 3

Vijayalaya-Colisvaratempel, Narttamalai, Tamil Nadu, $g^{e}$ eeuw. vele gopuras op met een granieten onderbouw die nog gaaf is, maar bekroond worden met een afgebrokkelde bakstenen bovenbouw. Ook in de eeuwen daarvoor werden torens van baksteen met stuc afgewerkt. Sommige overlevende torens lijken sprekend op natuursteen maar zijn in werkelijkheid van baksteen. Tenslotte zijn er ook aanwijzingen dat sommige tempels nooit een bovenbouw hebben gehad, ze zijn als bouwwerk onvoltooid gebleven. Dat levert geen beperkingen op in het gebruik, want anders dan kerktorens en minaretten heeft de toren van een Indiase atempel geen praktische 23 10:14:14AM betekenis, alleen een psychologische. 
Als de bovenbouw van een tempel ontbreekt, is het in de meeste delen van India geen open vraag hoe die er uit heeft gezien. In Karnataka echter komen de verschillende bouwstijlen naast elkaar voor en zijn er in principe verschillende mogelijkheden. Maar de tijd dat archeologen constateerden dat een bovenbouw geheel ontbreekt en het dus niet te zeggen is tot welke bouwstijl de tempel behoort, is voorbij. ${ }^{3}$ In de vorige eeuw was dat nog schering en inslag, maar niet meer sinds de publicatie van de drie bovengenoemde proefschriften. Bij een bepaalde onderbouw hoort maar één type bovenbouw.

\section{De kleine tempel in Halebid}

Halebid is een populaire toeristenbestemming in het zuiden van Karnataka vanwege een grote tempel (Hoysalesvara) met een ongeëvenaarde hoeveelheid overdonderend beeldhouwwerk. Er staan ook nog een paar kleinere tempels, waaronder één (Kedaresvara) die op de grote tempel lijkt en waarvan het beeldhouwwerk bijna even fraai is. Beide tempels hebben geen enkel spoor van een bovenbouw. Maar de kleine tempel had die nog wel in de $19^{\mathrm{e}}$ eeuw, er is een foto van gepubliceerd in 1902 ( $\mathrm{afb}$. 4). In het begin van de $20^{\mathrm{e}}$ eeuw is het monument opgeknapt en... de ingewikkelde resten van de bovenbouw zijn simpelweg verwijderd. Sindsdien staat de tempel er heel netjes bij, maar gruwelijk incompleet (afb. 5). De oude foto laat zien dat de bovenbouw volledig Dravida Vesara was, met details die bij verschillende andere soortgelijke tempels in de omgeving, met name in het naburige dorpje Harnahalli, nog te zien zijn. Reconstructie van de bovenbouw is daarom heel goed mogelijk en zou de tempel een heel ander aanzien geven. $\mathrm{Nu}$ is het alleen maar een stel muren met beeldhouwwerk en geen evenwichtige compositie.

\section{De grote tempel in Belur}

Deze tempel (Cennakesava) is niet alleen een populaire toeristenbestemming maar ook nog steeds een belangrijk pelgrimsdoel; de tempel leeft nog. $\mathrm{Hij}$ is groot en hij is gedecoreerd met wereldberoemd beeldhouwwerk. Hij werd in een paar jaar gebouwd in het begin van de $12^{\mathrm{e}}$ eeuw, maar gedurende de gehele $12^{\mathrm{c}}$ eeuw werd er nog beeldhouwwerk toegevoegd. Een bovenbouw ontbreekt. Er kan echter geen twijfel over bestaan dat die in de Nagara Bhumija-stijl gebouwd was, omdat de stervormige onderbouw is afgewerkt alsof de uitsprongen pilaren zijn. De sterpunten zijn helemaal identiek aan zware pilaren. Bij een van de ingangen van de hal van de tempel staat een miniatuur van een Nagara Bhumija-toren met dezelfde plattegrond, dit maakt een reconstructie eenvoudig. Bovendien zijn er verschillende $19^{\mathrm{e}}$ eeuwse foto's waarop zo een reusachtige Bhumija-toren te zien is! Een inscriptie vertelt dat de toren van de tempel in de $18^{\mathfrak{e}}$ eeuw tot twee keer toe werd gerenoveerd. In die periode werden in Karnataka heel andere torens gebouwd, de renovaties vonden niet plaats in de bouwstijl van de $18^{\mathrm{e}}$ eeuw. Een reproductie van wat er al was is daarom de logische gevolgtrekking. Het bouwvallige geheel werd verwijderd in het begin van de $20^{\mathrm{e}}$ eeuw. Een paar jaar geleden vond ik in de British Library een nog ongepubliceerde foto van de verwijderde toren die veel mooier is dan twee andere die wel gepubliceerd zijn (afb. 6, 7). De bouwmassa van deze toren is enorm en geeft de tempel een volslagen ander karakter. $l_{k}$ zou het veel beter winden hem $_{0}: 14: 14 \mathrm{Am}$ opnieuw te bouwen. 
ting

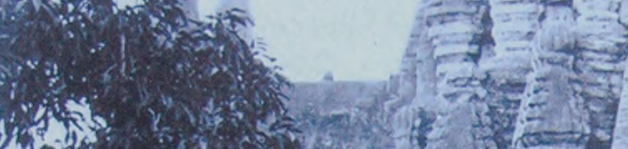

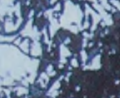

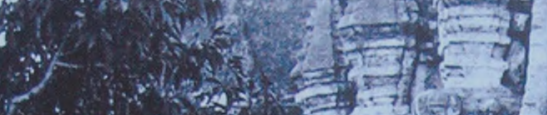

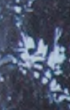

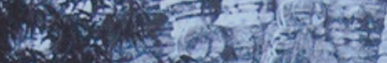

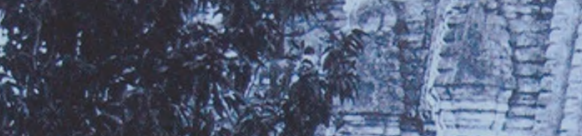

is

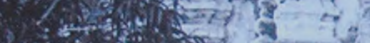

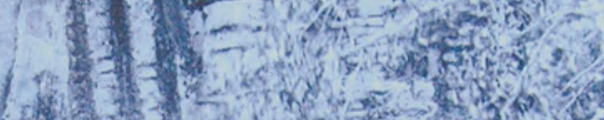

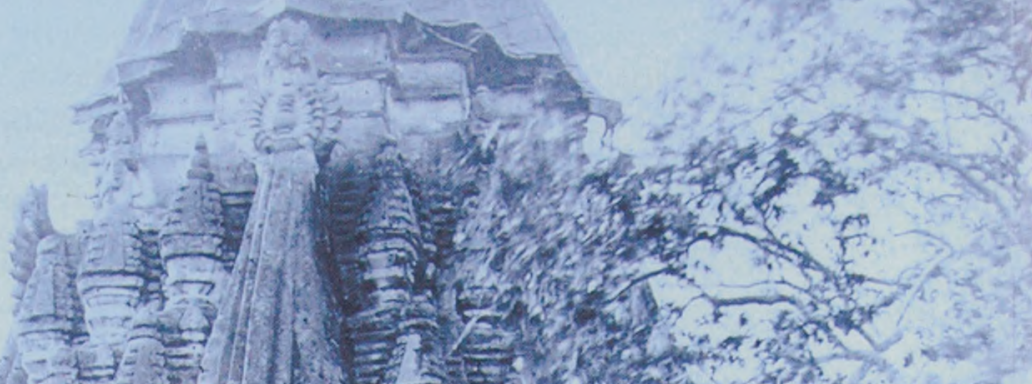

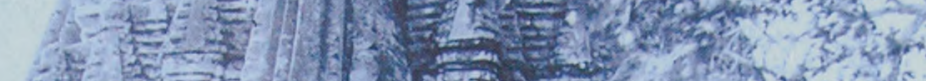

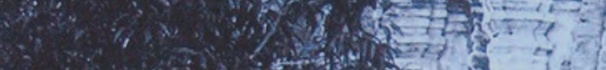

?

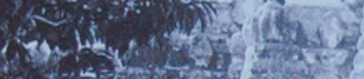
(1)

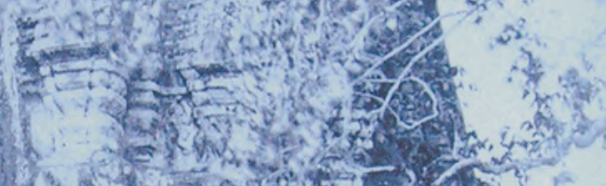

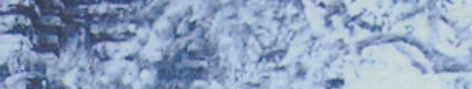

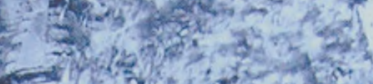

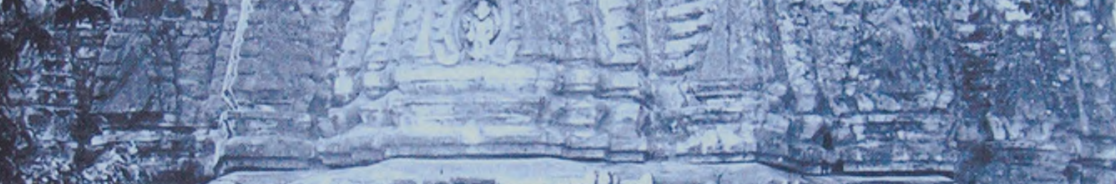

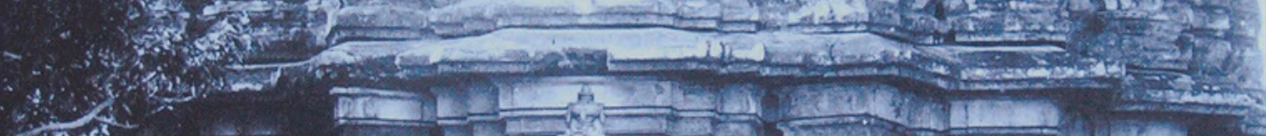
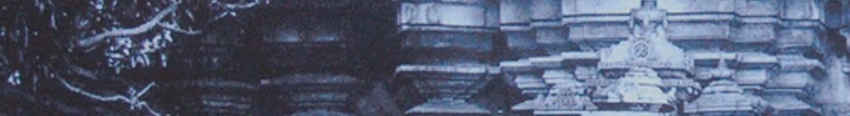

\%

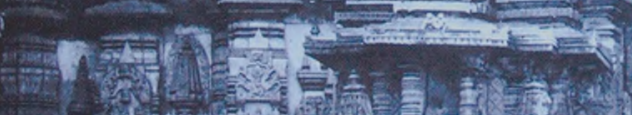

- $=-1$

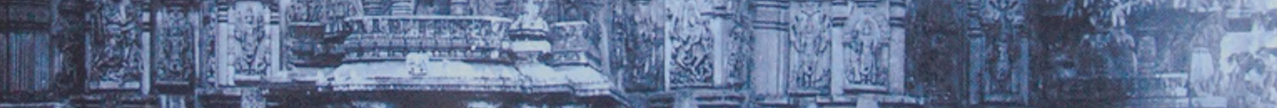

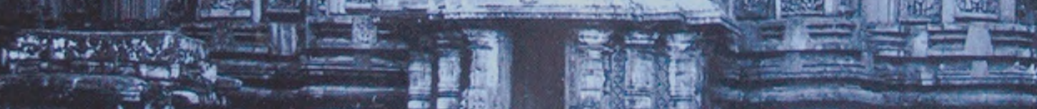

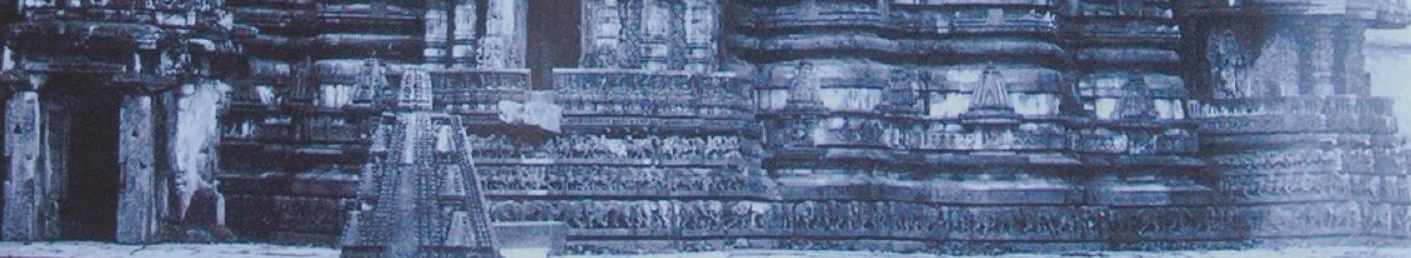
ing

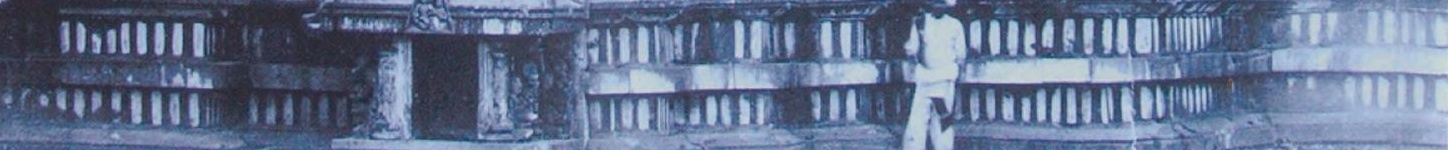




\begin{tabular}{|c|c|c|c|}
\hline $\begin{array}{l}\text { Afbeelding } 6 \text { (links) } \\
\text { Cennakesava-tempel, } \\
\text { Belur, Karnataka, } \\
12^{e} \text { eeuw. Deze foto laat } \\
\text { de bovenbouw zien die } \\
\text { in de } 19^{e} \text { eeuw nog aan- } \\
\text { wezig was. Hij werd } \\
\text { gemaakt door Henry }\end{array}$ & $\begin{array}{l}\text { Dixon, waarschijnlijk in } \\
\text { 1868, en is nog niet } \\
\text { eerder gepubliceerd. } \\
\text { Foto: British Library } \\
\text { Board, All Rights } \\
\text { Reserved, Indian } \\
\text { Museum 448, 1000/24 } \\
\text { (2333). }\end{array}$ & $\begin{array}{l}\text { Afbeelding } 7 \\
\text { Cennakesava-tempel, } \\
\text { Belur, Karnataka, } \\
12^{\mathrm{e}} \text { eeuw. Deze foto uit } \\
1997 \text { laat de tempel zien } \\
\text { in zijn huidige staat, } \\
\text { zonder toren. De inge- } \\
\text { tekende toren is afgeleid }\end{array}$ & $\begin{array}{l}\text { van het torentje voor de } \\
\text { ingang boven rechts, } \\
\text { omdat die precies } \\
\text { dezelfde stervormige } \\
\text { plattegrond heeft als de } \\
\text { buitenkant van de cella } \\
\text { van de tempel. }\end{array}$ \\
\hline
\end{tabular}

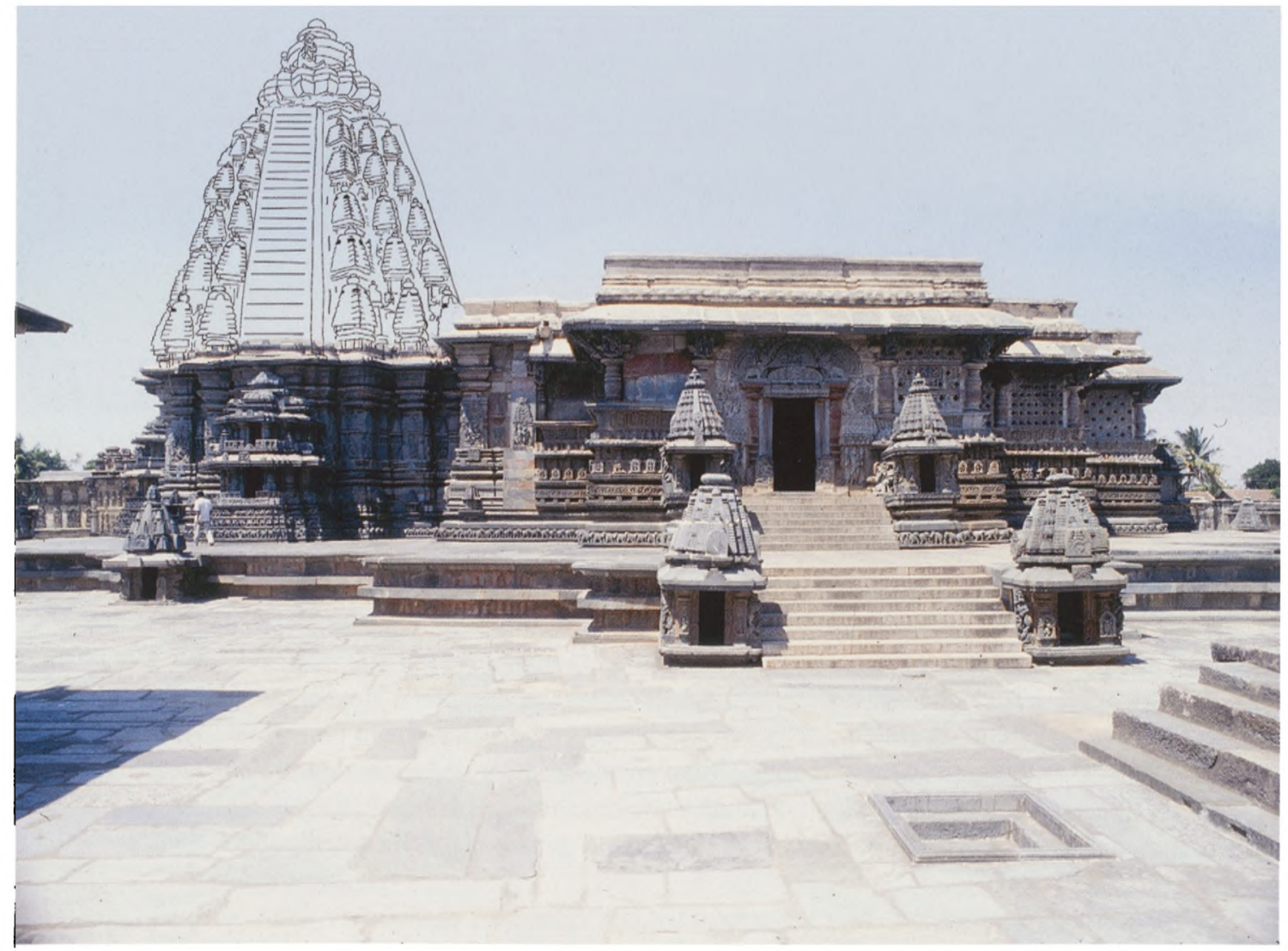

De grote tempel in Halebid

Zonder bovenbouw ziet een tempel er als geheel maar vormeloos uit en bij deze tempel (Hoysalesvara) wreekt dat zich dat nog eens extra omdat hij uit twee tempels bestaat die als een Siamese tweeling met elkaar zijn verbonden (afb. 8). Omdat de twee torens ontbreken is de opzet van de tempel van buiten af niet zichtbaar. De onderbouw laat duidelijk zien dat de torens Dravida Vesara moeten zijn, maar elk spoor ontbreekt en daarom vermoedt men dat ze nooit gebouwd zijn. Maar ook hier valt te overwegen de torens alsnog te bouwen, vereenvoudigd natuurlijk zodat duidelijk zichtbaar is dat $14: 14 \mathrm{AM}$ het toevoegingen betreft. 


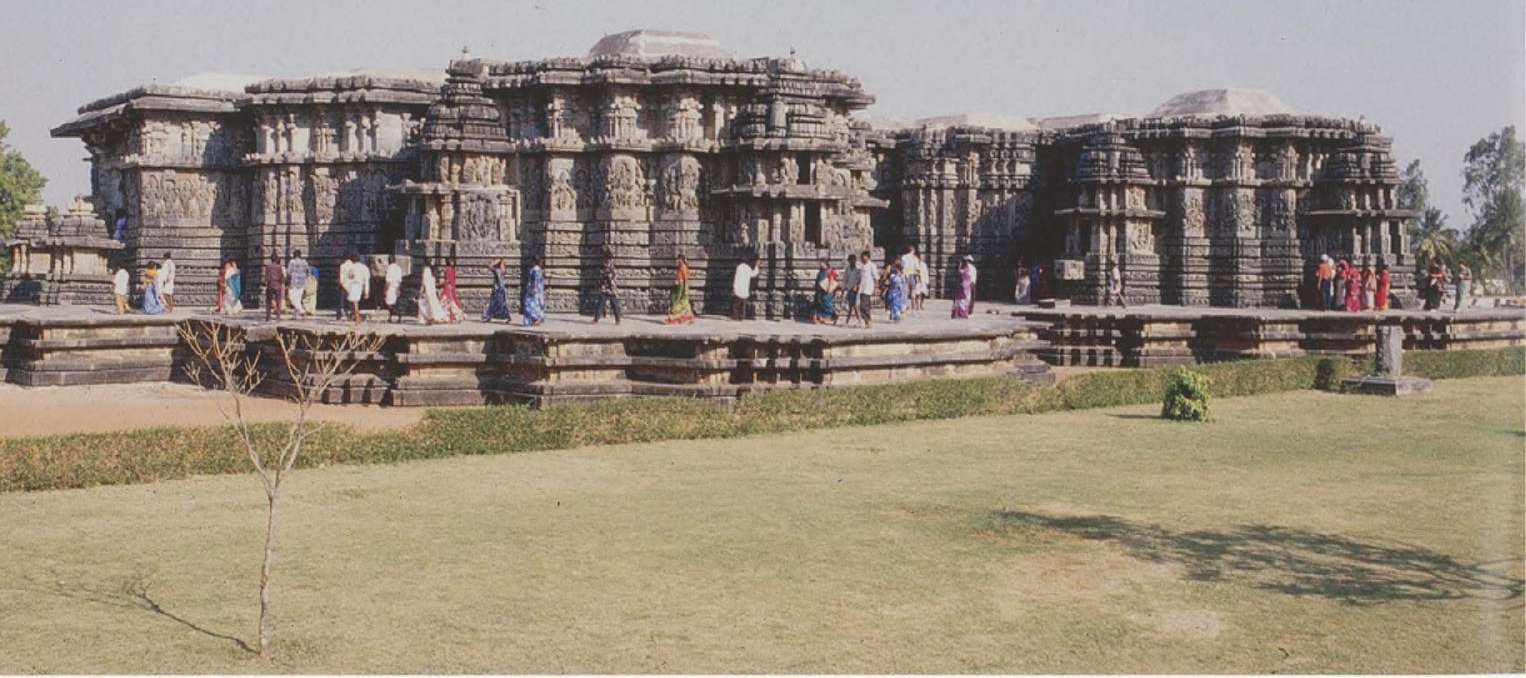

Afbeelding 8
Hoysalesvara-tempel,
Halebid, Karnataka,
$12^{\bullet}$ eeuw. Deze tempel
bestaat uit twee naast
elkaar liggende tempels
die onderling zijn ver-
bonden. Omdat torens
ontbreken is deze opzet
van buiten af ondui-
delijk. De bezoekers
wandelen langs zig-
zaggende muren.

Afbeelding 8

Conclusie

Piramideachtige torens zijn essentieel voor de aanblik van een hindoetempel. Meer dan in het geval van kerken en moskeeën zijn de torens geen toevoegingen aan het eigenlijke gebouw, maar een conceptueel onderdeel ervan.

Tenslotte een advies aan bezoekers van de beroemde Hoysala tempels in Belur en Halebid: blijf een dag langer en bezoek ook een paar kleine Hoysala tempels in de omgeving (Koravangala, Mosale, Belavadi, Haranhalli). Het beeldhouwwerk op de muren van deze tempels is bescheiden maar hun bovenbouw is goed behouden en van een fantastische detaillering.

\section{Noten}

* Met uitzondering van de twee $19^{e}$ eeuwse opnamen zijn alle foto's van de auteur.

1. G. Foekema, Architecture decorated with architecture. Later medieval temples of Karnataka, 1000-1300 AD, New Delhi, 2003.

2. Zie: A. Hardy, Indian Temple Architecture: Form and Transformation. The Karnata Dravida Tradition. $7^{\text {th }}$ to $13^{\text {th }}$ Centuries, New Delhi, 1995; A.J. Sinha, Imagining Architects. Creativity in the Religious Monuments of India, Londen, 2000; Foekema, Op.cit. (noot 1).

3. Zie: Ch.S. Patil, Temples of Raichur and Bellary Districts, Karnataka, 1000-1325 AD, Mysore, 1992. 